\title{
A case of Brucellosis with skin eruptions
}

\section{Deri döküntüleri olan Brucella olgusu}

• Yeșim Akpınar Kara

Liv Hospital, Clinic of Dermatology, Ankara, Turkey

\begin{abstract}
Brucellosis is the most widespread zoonotic infection. Severe complications involving the musculoskeletal, nervous, genitourinary, and cardiovascular systems could be encountered during the course of the disease. However, cutaneous complications are rarely discussed. I present a case of Brucella with vulvar abscess and skin purpura. Brucella is an infectious disease that should always be kept in mind in the differential diagnosis of skin rashes and lesions of the vaginal mucosa.
\end{abstract}

Keywords: Brucellosis, cutaneous manifestation, vaginal involvement

\section{Öz}

Brucella, dünya çapında görülen en yaygın zoonotik enfeksiyondur. Hastalığın seyri sırasında kas-iskelet, sinir, genitoüriner ve kardiyovasküler sistemleri ilgilendiren ciddi komplikasyonlarla karşılaşılabilir; ancak kutanöz komplikasyonlar nadiren bildirilmiştir. Burada vulvar bölgede apsesi ve deri purpurası olan Brucella olgusu sunulmaktadır. Deri döküntüleri ve vajinal mukozal bölge lezyonlarında Brucella'nın da ayıııc tanıda daima akılda tutulması gereken bir enfeksiyon hastalığı olduğunu vurgulamak istiyorum.

Anahtar Kelimeler: Brucella, deri bulguları, vajinal tutulum

\section{Introduction}

Brucellosis is caused by a Gram-negative Coccobacillus of the genus Brucella. It is a disease that can be transmitted from animals to humans under certain circumstances ${ }^{1}$. It is still endemic in many countries, especially in the Mediterranean areas $^{2}$ and is most commonly transmitted after consumption of raw milk, cheese or contact with infected animals. Human brucellosis has a wide clinical spectrum. Hence, it is difficult to diagnose as it mimics many other diseases ${ }^{3}$. Brucellosis is a multisystemic disease that usually presents with a broad spectrum of clinical manifestations and complications.
Skin lesions occur in approximately $5-10 \%$ of patients with brucellosis ${ }^{4}$. Many non-specific transient lesions are reported such as rashes, papules, ulcers, abscesses, erythema nodosum, petechiae, purpura, and vasculitis ${ }^{5}$. In this study, we describe a patient with brucellosis presenting with papules and nodules on the axilla and vulvar mucosa.

\section{Case Report}

A 34-year-old veterinary female professional was admitted to the dermatology outpatient clinic with fever, arthralgia, myalgia, and papulonodular eruptions on her skin for

\footnotetext{
Address for Correspondence/Yazıșma Adresi: Yeșim Akpınar Kara MD, Liv Hospital, Clinic of Dermatology, Ankara, Turkey Phone: +90 5358858855 E-mail: yesim_akpinar@yahoo.com Received/Geliş Tarihi: 17.04.2021 Accepted/Kabul Tarihi: 06.09.2021 ORCID: orcid.org/0000-0003-3834-1858
}

Cite this article as: Akpınar Kara Y. A case of Brucellosis with skin eruptions. Turkderm-Turk Arch Dermatol Venereol 2021;55:203-5 
three days. Although she received non-specific antibiotic treatment, there was no improvement in the skin lesions. Physical examination revealed an ulcerated maculapapular lesions on the right axilla and exudative abscess in the labia majora (Figure 1,2) There was a painful violet-erythematous plaque on the heel of her right foot (Figure 3). Serological tests results for venereal disease research laboratory-rapid plasma reagin, anti-human immunodeficiency virus, herpes simplex 1-2 immunoglobulin M (IgM)-lgG, varicella-zoster IgM-lgG, Epstein-Barr virus, anti-hepatitis $C$ virus, anti-HBs virus were negative unlike $C$-reactive protein: $27.6 \mathrm{mg} / \mathrm{dL}$ (N: 0-8). Brucella agglutinin titer was positive at $1 / 640$ titration. A skin biopsy was not performed as the patient refused the procedure. After a diagnosis of brucellosis was made, the patient was treated with doxycycline $100 \mathrm{mg}$ per os twice daily, and rifampicin $600 \mathrm{mg}$ per os once daily. Five days after treatment, her skin lesions and other complaints regressed. Informed consent was obtained.

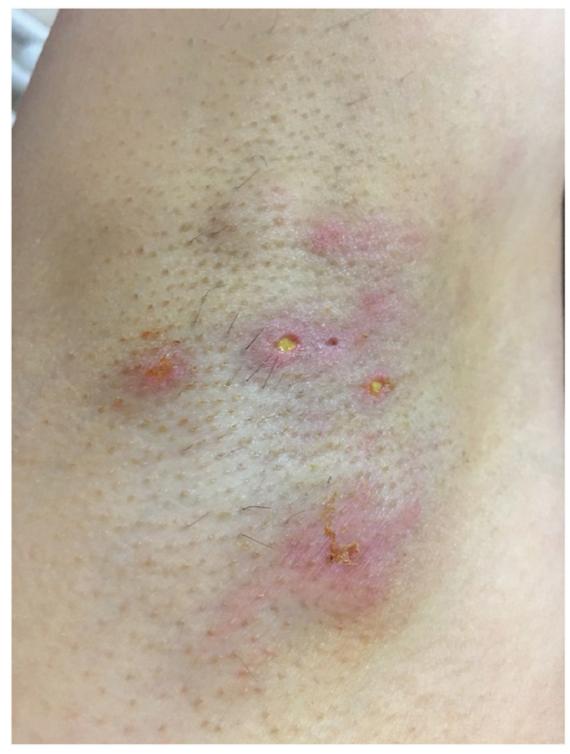

Figure 1. Maculapapuler lesions on right axilla

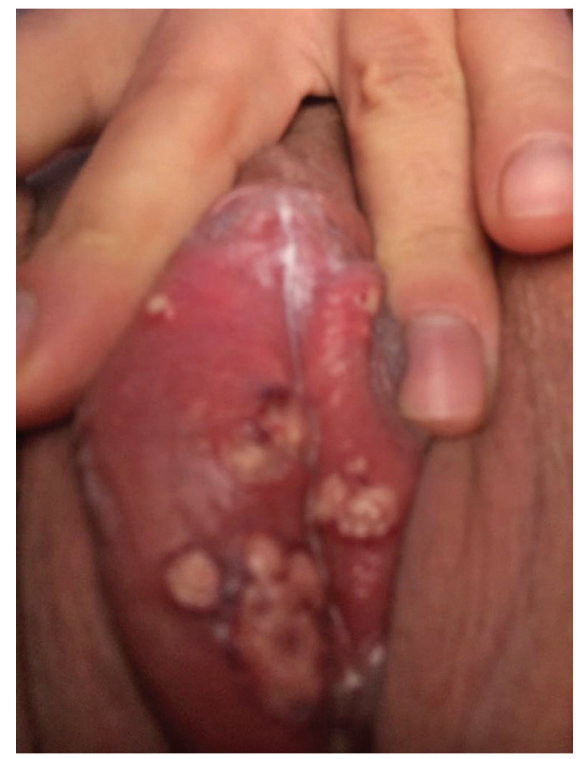

Figure 2. An Exudative abscess in the labia majora

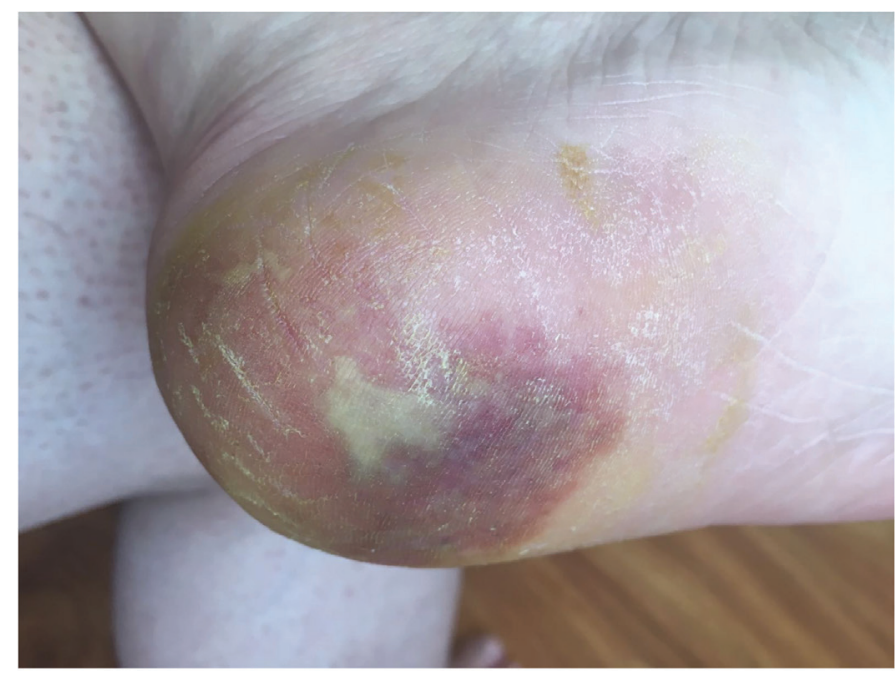

Figure 3. The violet-erythematous plaque on the heel of the foot

\section{Discussion}

Brucellosis with skin symptoms was first described in $1940^{6}$. From then, cutaneous symptoms have not been well defined. Ariza et al. ${ }^{7}$ reported that cutaneous manifestations developed in $6 \%$ of the patients with brucellosis. Cutaneous manifestations are related to hypersensitivity reactions or a combination of immune complexes ${ }^{7,8}$. Brucella can mimic many diseases. Ariza et al. ${ }^{7}$ detected papulonodular eruptions, erythema nodosum, purpura, subcutaneous abscess, and diffuse maculopapular rash as the most common cutaneous manifestations of the disease.

It has been considered as contact dermatitis, especially in veterinarians. Trunnell et al. ${ }^{9}$ found that this is a reaction due to hypersensitivity. These lesions were generally observed in the contact area and upper extremities. In previous studies, subcutaneous abscesses were reported in patients with brucellosis through occupational contact. Al Abdely et al. $^{10}$ reported a case of a patient with a breast abscess caused by Brucellosis. In a previous study, vaginal abscess associated with brucellosis was not encountered. Our case was that of a veterinarian woman with occupational exposure to Brucella presenting with mucocutaneous abscesses and maculopapuler lesions. Although vulvar involvement has not been described in patients with brucellosis, a case with macuopapular rash, vasculitis, and erythema nodosum-like lesions have previously been reported. Histologic examination of tissue following punch biopsy from cases with multiple abscesses in the breast and knee revealed a non-specific granulomatous reaction ${ }^{8,11}$. These lesions resulted from hematogenous spread ${ }^{10}$. In previous studies, petechiae and purpura formation were encountered in patients with brucellosis ${ }^{12,13}$. In our case, purpura formation was observed in the heel area of the foot. The mechanism responsible for thrombocytopenia in brucellosis is hemophagocytosis and immune destruction of platelets and the presence of antiplatelet antibodies has been demonstrated in some patients ${ }^{8}$.

Nonetheless, cutaneous lesions are not specific to brucellosis and may be seen in a variety of other dermatologic diseases caused by many other agents. Therefore, Brucellosis should be as a differential diagnosis of vulvar mucosal eruptions with fever and cutaneous manifestations. 


\section{Ethics}

Informed Consent: It was obtained.

Peer-review: Externally and internally peer-reviewed.

Financial Disclosure: The author declared that this study received no financial support.

\section{References}

1. Wang W, Lu X, Li C, Ri MJ, Cui W: A man with recurrent fever, arthritis, and rashes-brucellosis? A case report. BMC Infect Dis 2020;20:18.

2. Perez A, Berhe M: Brucella, a bacterium with multiple ways of causing infection. Proc (Bayl Univ Med Cent) 2020;34:99-101.

3. Shahcheraghi SH, Ayatollahi J: Skin rashes on leg in Brucellosis: a rare presentation. Acta Med Iran 2015;53:387-8.

4. Akcali C, Savas L, Baba M, Turunc T, Seckin D: Cutaneous manifestations in Brucellosis: A prospective study. Adv Ther 2007;24:706-11.

5. Ayaslioglu E, Koçak M, Bozdogan O: A case of brucellosis presenting with widespread maculopapular rash. Am J Dermatopathol 2009;31:687-90.
6. Piulachs P, Vidal-Barraquer F: Cutaneous lesions in brucellosis; new etiological type of ulcer of the lower extremities. Rev Clin Esp 1951;6:388-93.

7. Ariza J, Servitje O, Pallarés R, et al.: Characteristic cutaneous lesions in patients with brucellosis. Arch Dermatol 1989;125:380-3.

8. Milionis $\mathrm{H}$, Christou L, Elisaf M: Cutaneous manifestations in brucellosis: Case report and review of the literature. Infection 2000;28:12-6.

9. Trunnell TN, Waisman M, Trunnell TL: Contact dermatitis caused by Brucella. Cutis 1985;35:379-81.

10. Al Abdely HM, Halim MA, Anim TM: Breast abscess caused by Brucella melitensis. J Infect 1996;33:219-20.

11. Christianson HB, Pankey GA, Applewhite ML: Ulcers of the skin due to Brucella suis: report of a case. Arch Dermatol 1968;98:175-6.

12. Guzel Tunccan O, Dizbay M, Senol E, Aki Z, Ozdemir K: Isolated severe immune thrombocytopenia due to acute Brucellosis. Indian J Hematol Blood Transfus 2014;30(Suppl1):27-9.

13. Buzgan $T$, Karahocagil MK, Irmak $H$, et al.: Clinical manifestations and complications in 1028 cases of brucellosis: a retrospective evaluation and review of the literature. Int J Infect Dis 2010;14:469-78. 